\title{
Use of passive sampling to identify organic pollutants in groundwater
}

\author{
N. Mali ${ }^{1} \&$ P. Auersperger ${ }^{2}$ \\ ${ }^{1}$ Geological Survey of Slovenia, Ljubljana, Slovenia \\ ${ }^{2}$ Public Water Supply Company Vodovod-Kanalizacija, Slovenia
}

\begin{abstract}
The anthropogenic organic pollutants have been recognized as one of the important factors in environmental pollution. Strict legislation concerning the quality of drinking water in the EU requires the optimisation of analytical methods for organic pollutants. Commonly used monitoring systems usually only record pollutant concentrations at a specific point in time. Contrary passive samplers cover a long sampling period, integrating the pollutant concentration over time. This paper presents the application of passive sampling for a quality monitoring of organic contaminants in a coarse gravel aquifer Vrbanski plato which presents the main drinking water resource for Maribor, the second largest city in Slovenia. Passive sampling devices with granular activated carbon were applied in 15 observation wells and in the Drava River. In 9 monitoring points, passive samplers were applied at different depths of the saturated zone. Two sampling series covered the period of one year. In both series, 161/166 organic compounds were identified. The frequency and intensity of the identification has been determined for all the compounds. Forty detected organic compounds were classified in different pollutant groups with respect to their origin (urban source, agriculture or industry). An analysis of the presence of organic substances in the two periods, spring-summer and autumn-winter, was carried out. It showed that substances of agricultural origin were more present in the first period, while those of urban and industrial origin occurred more frequently in the second period. Passive sampling was proved as an appropriate tool for assessing aquifer contamination with organic compounds.
\end{abstract}

Keywords: groundwater, monitoring, passive sampling, GC-MS, organic pollutants 


\section{Introduction}

Anthropogenic organic pollutants have been recognized as one of the important factors in environmental pollution. They have been found as contaminants in sewage, surface waters, and groundwater, as well as in drinking water. The attention of researchers was a decade ago focused on the detection of classical pollutants in water, e.g. pesticides, nitrates and PCBs, while today their aim is also to determine the presence of hormones, pharmaceuticals, personal care products and other household and industrial chemicals.

The presence of anthropogenic organic pollutants in the aquatic environment results in an increasing demand for sensitive and reliable monitoring tools for these contaminants in groundwater [1]. Developments in the assessment of water quality require the improvement of analytical methods and appropriate sampling technology to support monitoring programs. Strict legislation concerning the quality of drinking water in the EU requires the optimization of analytical methods for organic pollutants. Commonly used monitoring systems usually record only pollutant concentrations at a specific point in time. Contrary to dynamic techniques, passive sampling is less sensitive to accidental extreme variations of the organic pollutant concentrations in natural waters [2]. A passive sampler can cover a long sampling period, integrating the pollutant concentrations over time. Over the monitoring period, analytical costs can be reduced substantially. The concept of monitoring is very important, where the first preliminary qualitative methods are used to assess the situation, and are later supported by precise and accurate quantitative analytical methods. Passive sampling is less sensitive to accidental extreme variations of the organic pollutant concentration in natural waters than dynamic techniques [2]. Passive sampling techniques have proven as useful monitoring tools for a range of different contaminants in the aquatic environment [1, 3-5].

Intensive land use in the area of the Vrbanski plato aquifer may result in the contamination of those groundwater resources which represent the main drinking water supply for Maribor, the second largest city in Slovenia. The aim of the presented study was to investigate the presence of organic pollutants in a coarse gravel aquifer of the Vrbanski plato. To reach the goal, the passive sampling techniques for quality monitoring of organic contaminants were applied.

\section{Study area}

Maribor is the second largest city in Slovenia and the capital of the north-east region (Fig. 1). In the past, the economy was based on heavy industry which left its mark on the environment. Today, mostly commercial business takes place in the industrial area. The urban area has a relatively well-regulated public utility. The problematic issue is an old sewage system in some places, or lack of it on the periphery. A potential source of groundwater pollution in the Vrbanski plato aquifer is also intensive agriculture on the outskirts of the city. 


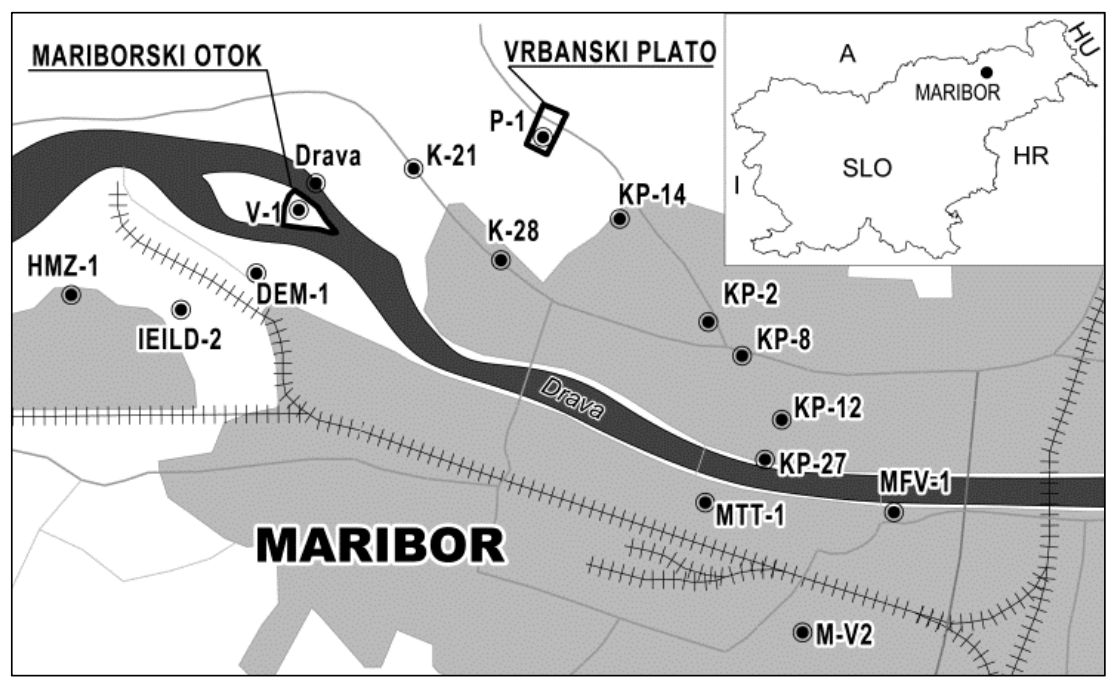

Figure 1: Study area.

The Vrbanski plato aquifer is situated under the Maribor city, and is the most important drinking water resource of the region. There are two pumping stations, one on Vrbanski plato, where 400-500 1/s of water are pumped, and the second one at Mariborski otok with $150 \mathrm{l} / \mathrm{s}$ of water pumped. The water from MO is used for artificial recharge of groundwater in the Vrbanski plato. The aquifer represents old gravel deposits of the Drava River. It is an intergranular aquifer with high permeability and unconfined groundwater table [6]. The thickness of the gravel layer is up to $40 \mathrm{~m}$, the groundwater level is at a depth of $25-37 \mathrm{~m}$, the maximum thickness of the saturated zone is $13 \mathrm{~m}$. The hydraulic conductivity of the principal aquifer has been reported from $5 \times 10^{-3} \mathrm{~m} / \mathrm{s}$ to $2 \times 10^{-2} \mathrm{~m} / \mathrm{s}[6,7]$.

The region has a moderate climate with a typical continental precipitation regime and an average yearly precipitation between 1100 and $1200 \mathrm{~mm}$. The mean annual temperature varies between 8 and $10^{\circ} \mathrm{C}$.

\section{Materials and methods}

\subsection{Sampling}

The monitoring network was set up according to the hydrogeological characteristics of the aquifer, the direction of groundwater flow and the land use. Passive sampling devices with granular activated carbon were applied into 15 observation wells and into the Drava River, which represents one of the aquifer's recharge components. Sampling points were selected in the recharge area of the active pumping stations, Mariborski otok and Vrbanski plato. In 9 monitoring points, passive samplers were applied at different depths in the saturated zone. Two sampling series covered the period of one year. The first spring/summer series covered the period from May 2010 to September 2010, the 
second autumn/winter from September 2010 until the end of March 2011. There was $423 \mathrm{~mm}$ of precipitation in the first and $313 \mathrm{~mm}$ in the second period. A total of 54 samples were collected.

\subsection{Passive samplers and analytical methods}

In presented research, passive sampling devices with granular activated carbon were applied. Activated carbon (approx. $3 \mathrm{~g}$ ) was inserted into the passive sampler made of $1 \mathrm{~mm}$ mesh pouches and installed to $1 \mathrm{~mm}$-thick wire. All devices were made of stainless steel.

All chemical analyses were performed in the laboratory of Javno Podjetje Vodovod - Kanalizacija D.O.O. in Ljubljana. After collection, active carbon fibers were transferred immediately into vial and transported to laboratory. The adsorbed material on the passive sampler was eluted from the activated carbon with dichloromethane, and the extract was further transferred to chromatographic vials and concentrated in a stream of nitrogen. For the interpretation of chromatograms, the AMDIS deconvolution was used. The deconvolution was covered by GC-MS library with retention times for 921 organic contaminants from Agilent USA, and also the NIST 2008 library of mass spectra [8]. Despite the fact that the method is qualitative, GC-MS chromatograms were interpreted with an estimate of peak intensities with a ranking scale from 1 to 5 and the comment "tentative identification" or "confirmed identification" according to ASTM D 4128-01. The estimate of peak intensity is connected with the certainty of identification and gives a starting point for quantitative monitoring of compounds [9].

\section{Results and discussion}

In two sampling series, 161/166 organic compounds were identified, with a total of 66 compounds specified altogether. An evaluation of different groups of pollutants according to their origin (urban, agricultural and industrial pollution) has been performed. The list of compounds is given by groups in Table 1. For each substance, a potential source has been defined.

Forty of the most typical substances were determined in groups. In addition to the three main groups, two other groups were excluded: the pharmaceutical residues, which are an indicator of urban pollution, and petroleum products.

In the group of agricultural pollutants (9), pesticides and their metabolites (atrazine, simazine, propazine, terbuthylazine, metolachlor) are commonly used. In a group of urban pollutants, 15 substances were determined. In a separate group of pharmaceuticals (3), carbamazepine, methyl salicylate and caffeine were classified. Among industrial pollutants, chlorinated solvents have been classified (10). Substances from the group of oil products may be indicators of both, urban and industrial pollution (3).

An analysis of the identification of 40 selected components was done according to the frequency and intensity of identification. We compared the two sampling series. Figs 2 and 3 show an overview of the most commonly defined compounds and a review of intensity of the selected compounds for both periods. 
Table 1: List of detected organic compounds (numeric code represents the individual substance, shown in Figs 4-6).

\begin{tabular}{|c|c|c|c|}
\hline Group & Code & Substance & Source \\
\hline Agriculture & $\begin{array}{l}3 \\
4 \\
5 \\
6 \\
7 \\
8 \\
9\end{array}$ & $\begin{array}{l}\text { atrazine } \\
\text { compound with major } \\
\text { fragments } \mathrm{m} / \mathrm{z} 162,282 \\
\text { desethylterbuthylazine } \\
\text { desethylatrazine } \\
\text { dimethomorph } \\
\text { metolachlor } \\
\text { propazine } \\
\text { simazine } \\
\text { terbuthylazine }\end{array}$ & $\begin{array}{l}\text { herbicide } \\
\text { degradation product of herbicide } \\
\text { metolachlor } \\
\text { degradation product of herbicide } \\
\text { terbuthylazine } \\
\text { degradation product of herbicide atrazine } \\
\text { fungicide } \\
\text { herbicide } \\
\text { herbicide } \\
\text { herbicide } \\
\text { herbicide }\end{array}$ \\
\hline Urban & $\begin{array}{l}10 \\
11 \\
12 \\
13 \\
14 \\
15 \\
16 \\
17 \\
18 \\
19 \\
20 \\
21 \\
22 \\
23\end{array}$ & $\begin{array}{l}\text { 2,4-dichlorophenol } \\
\text { 2,6-dimethoxy-1,4- } \\
\text { benzoquinone } \\
\text { 2-methyl-2H-benzotriazole } \\
6 \beta \text {-Methylpregn-4-ene-3,20- } \\
\text { dione } \\
\text { alpha-pinene } \\
\text { benzaldehyde } \\
\text { benzothiazole } \\
\text { cholesterol } \\
\text { dimethyl disulfide } \\
\text { dimethyl trisulfide } \\
\text { erythritol } \\
\text { gibberellin A9 } \\
\text { m- + p- xylene } \\
\text { nicotine } \\
\text { sulphur S8 }\end{array}$ & $\begin{array}{l}\text { biocide, chemical intermediates } \\
\text { natural compound } \\
\text { herbicides, antimicrobial agents, UV } \\
\text { absorbers, corrosion inhibitors } \\
\text { steroid } \\
\text { insecticide, cosmetic, solvent, plasticizers } \\
\text { chemical intermediates, solvent, bee } \\
\text { repellents } \\
\text { rubber additive, antimicrobial agents, } \\
\text { flavors } \\
\text { steroid, manure, septic tanks, sewage } \\
\text { intrusion } \\
\text { natural compound, petroleum products } \\
\text { natural compound, petroleum products } \\
\text { artificial sweeteners } \\
\text { natural fungicide } \\
\text { petroleum products, chemical } \\
\text { intermediates } \\
\text { natural compound, tobacco } \\
\text { petroleum products, decomposition of } \\
\text { tyres, reduction of sulphate }\end{array}$ \\
\hline Pharmaceuticals & $\begin{array}{l}25 \\
26 \\
27\end{array}$ & $\begin{array}{l}\text { caffeine } \\
\text { carbamazepine } \\
\text { methyl salicylate }\end{array}$ & $\begin{array}{l}\text { urbane waste waters } \\
\text { drug } \\
\text { drug }\end{array}$ \\
\hline
\end{tabular}


Table 1: Continued.

\begin{tabular}{|c|c|c|c|}
\hline Group & Code & $\mathrm{Su}$ & \\
\hline Industry & $\begin{array}{l}31 \\
32 \\
33 \\
34 \\
35 \\
36 \\
37\end{array}$ & $\begin{array}{l}\text { 1,2,3-trichlorobenzene } \\
\text { 1,2,4-trichlorobenzene } \\
\text { 1,4-dioxane } \\
\text { 2-ethyl-3-methylmaleimide } \\
\text { 3,4-dimethyl-2,5-furandione } \\
\text { tetrachloroethene } \\
\text { tribromomethane } \\
\text { trichloroethene } \\
\text { triethylphosphate } \\
\text { tris(2-chloroethyl) phosphate }\end{array}$ & $\begin{array}{l}\text { degreasing, pigments, chemical intermediates } \\
\text { insecticide, degreasing, pigments, chemical } \\
\text { intermediates } \\
\text { oxygenate, solvent, stabilizer in halogenated } \\
\text { solvents } \\
\text { natural compound } \\
\text { chemical intermediates } \\
\text { dry cleaning, degreasing, industrial solvent } \\
\text { solvent, chemical intermediates } \\
\text { dry cleaning, degreasing, industrial solvent } \\
\text { plasticizer } \\
\text { flame retardant }\end{array}$ \\
\hline $\begin{array}{l}\text { Oil } \\
\text { derivatives }\end{array}$ & $\begin{array}{l}39 \\
40\end{array}$ & $\begin{array}{l}\text { o-xylene } \\
\text { toluene }\end{array}$ & $\begin{array}{l}\text { petroleum products, chemical intermediates, } \\
\text { synthesis of styrene } \\
\text { petroleum products, chemical intermediates } \\
\text { petroleum products, chemical intermediates, } \\
\text { solvent, denaturant }\end{array}$ \\
\hline & & $\begin{array}{l}\text { 1-(2,4,6-trihydroxyphenyl)butan- } \\
\text { 1-one } \\
\text { 1,1,4,4-tetrachlorobutadiene } \\
\text { 2-(Methylthio)benzothiazole } \\
\text { 2,2'-Methylenebis(4-methyl-6-t- } \\
\text { butylphenol) } \\
\text { 3,5-dichloroaniline } \\
\text { benzenesulfonamide } \\
\text { bromacil } \\
\text { chloroiodomethane } \\
\text { diethyltoluamide } \\
\text { diurone or linurone (as 3,4- } \\
\text { dichlorophenyl isocyanate) } \\
\text { fenarimol } \\
\text { fipronil } \\
\text { fluoroimide } \\
\text { fluridon } \\
\text { galaxolide } \\
\text { hexachloro-1,3-butadiene } \\
\text { isomers of tetramethylbenzene } \\
\text { isomers of trimethylbenzene } \\
\text { metalaksyl } \\
\text { naphthalene } \\
\text { N-butylbenzenesulfonamide } \\
\text { pirimicarb } \\
\text { prometryn } \\
\text { pyrene } \\
\text { secbumeton } \\
\text { triphenyl phosphate }\end{array}$ & $\begin{array}{l}\text { plastic ingredient } \\
\text { industrial chemical } \\
\text { tyres, industrial waste water } \\
\text { antioxidant, stabilizer for polymers } \\
\text { chemical intermediates } \\
\text { degradation product of herbicide bensulide } \\
\text { herbicide } \\
\text { natural compound } \\
\text { insect repellent } \\
\text { thermal decomposition of herbicides linuron } \\
\text { and diuron } \\
\text { fungicide } \\
\text { insecticide } \\
\text { fungicide } \\
\text { herbicide } \\
\text { musk compounds, cosmetic } \\
\text { solvent, coolants } \\
\text { petroleum products, chemical intermediates, } \\
\text { synthesis of styrene } \\
\text { petroleum products } \\
\text { herbicide } \\
\text { chemical intermediates, moths repellent } \\
\text { plasticizer, metabolite of chlorobenzenes } \\
\text { insecticide } \\
\text { herbicide } \\
\text { chemical intermediates, incomplete } \\
\text { combustion of fossil fuels, tar } \\
\text { herbicide } \\
\text { plasticizer, flame retardant, lubricant }\end{array}$ \\
\hline
\end{tabular}



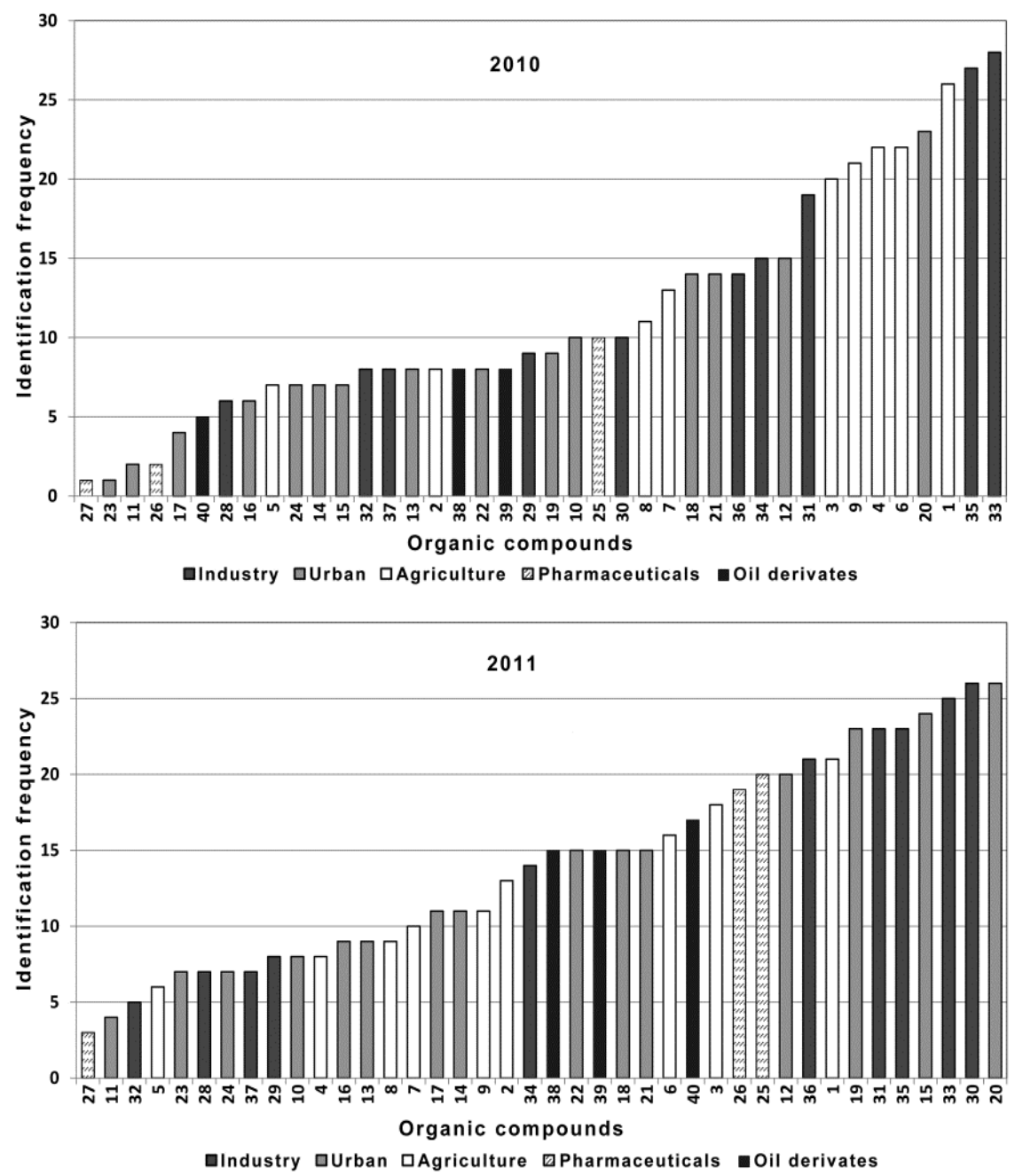

Figure 2: $\quad$ Identification frequency of selected organic pollutants (Year 2010, 2011). 

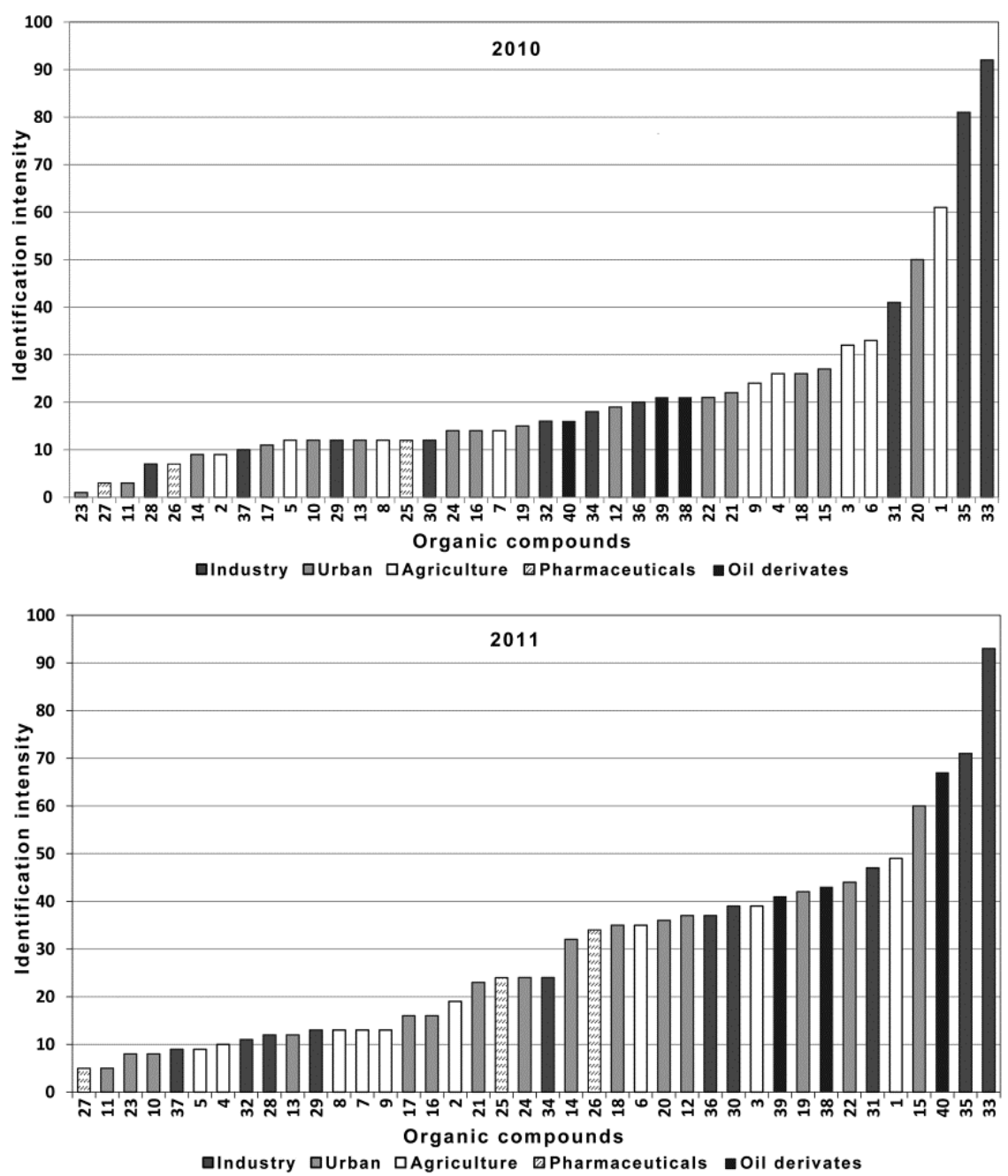

Figure 3: Identification intensity of selected organic pollutants (Year 2010, 2011).

The comparison of both series of results shows that the intensity and frequency of identification in the second series (dry season $-313 \mathrm{~mm}$ ) are higher than in the first series $(423 \mathrm{~mm})$. The intensity and frequency vary by individual parameters. In the first series, indicators of agricultural pollution (pesticides) are more intense, whereas those of urban and industrial pollution prevail in the second series. Tetrachloroethene and trichloroethene have the largest frequency identification in the first series, followed by erythritol and pesticides atrazine, metolachlor, desethylterbuthylazine, terbuthylazine and desethylatrazine. Next are the substances of urban and industrial pollution; pharmaceuticals are detected only a 
few times. In the second series, next to trichloroethene and tetrachloroethene, most often determined are erythritol, 1,4-dioxane, benzaldehyde, trichloroethane, 2-ethyl-3-methylmaleimide etc. (Figs 2 and 3). Among pesticides, atrazine is the most frequently detected, whereas other pesticides were detected less often. Much higher frequencies of identification in the second series belong to carbamazepine and caffeine.

The intensity reacts similarly to the frequency of identification. The intensity of trichloroethene and tetrachloroethene dominated in both series. In the second series, intensities of most pesticides decrease or remain the same. However, the intensities of benzaldehyde, $\mathrm{m}$ - + p- xylene, dimethyl trisulfide and all petroleum products (toluene, ethylbenzene, o-xylene) are increased.

In the diagrams, analyses of the frequency by the intensity of identification are presented by groups (Figs 4-6). Results in the group of pesticides show a high detection of atrazine, metolachlor and desethylatrazine in both series, and terbuthylazine and desethylterbuthylazine in the first series. In the second series, a decrease in the frequency of identification is observed in all contaminants except in the metolachlor degradation product $\mathrm{m} / \mathrm{z} 162.282$, the intensity of which, and also that of desethylatrazine, markedly increases in the second series. It can be concluded that during the autumn-winter period, concentrations of pesticides in groundwater are lower because they are mostly used in the spring period. Due to higher precipitation during spring period, the leaching of pesticides from the fields increases. On the contrary, the results show the increased values of their metabolites during the autumn-winter period.

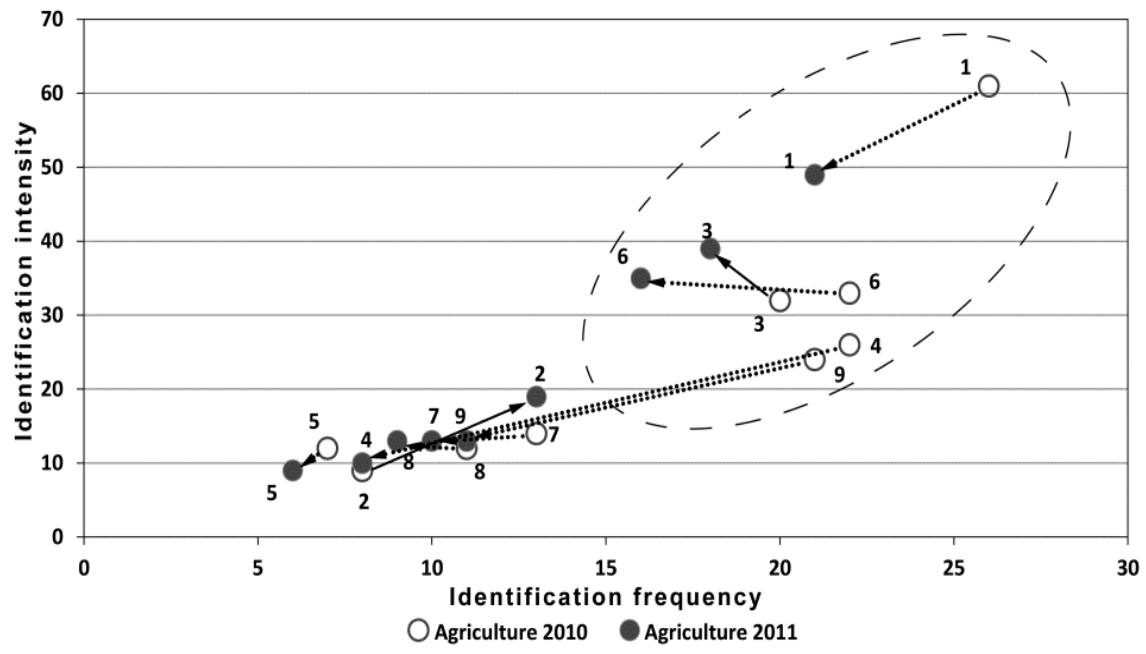

Figure 4: Graph of frequency vs. intensity of organic compounds identification - Agriculture (numbers in the graph represent codes of organic compounds given in Table 1). 


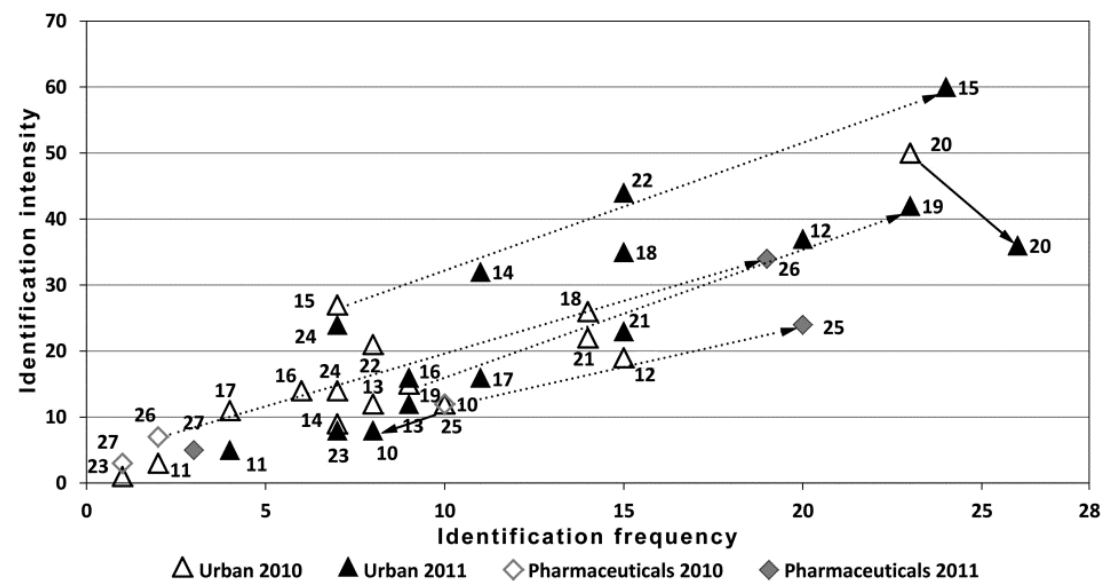

Figure 5: Graph of frequency vs. intensity of organic compounds identification - Urbane (numbers in the graph represent codes of organic compounds given in Table 1).

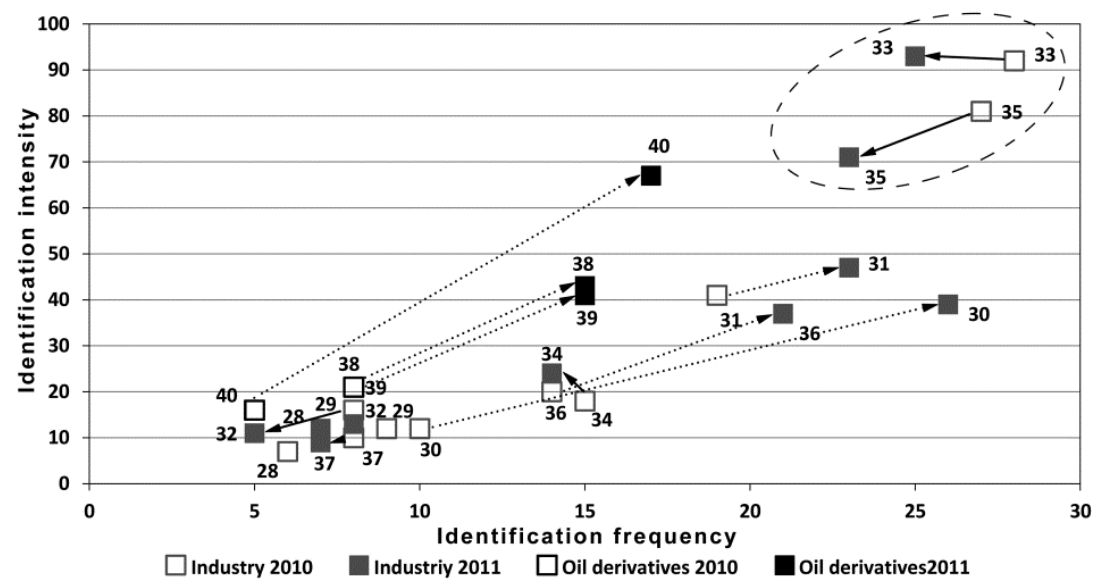

Figure 6: Graph of frequency vs. intensity of organic compounds identification - Industrial (numbers in the graph represent codes of organic compounds given in Table 1).

In the group of urban pollutants, both the frequency and intensity of identification have increased for all compounds, except for 2,4-dichlorophenol and erythritol. Both parameters for 2,4-dichlorophenol fall in the second series, for erythritol the number of identifications increases and the intensity decreases. The maximum ascents of both parameters are at benzaldehyde, carbamazepine, dimethyl trisulfide and caffeine.

Tetrachloroethene and trichloroethane achieve the highest values of frequency and intensity in the group of industrial pollutants. Values of the total intensity are 
recorded from 71 to 93 and frequency values are between 23 and 28. For both compounds, the values in the second series are lower. The chart shows a great increase in the values of oil derivatives and 1,4 dioxane, as well as triethyl phosphate.

Based on the results it can be concluded that in the spring period there are higher concentrations of pesticides in groundwater from agricultural origin due to the increased use and leaching from agricultural area. In the autumn-winter (dry) period there is neither a new injection, nor leaching of the pesticides. On the contrary, the presence of organic compounds from urban and industrial pollution increases. In most cases, the sources of pollution are sewage and discharges of waste water. The sewage system in the city has been partly renewed, yet there are parts where the network is very old and the losses are rather large. There are even areas with no regulated sewerage (that have no organized sewage system). We assume that the losses in the sewage systems and emission are constant throughout the year. Thus, in the period of higher groundwater level and during great rainfall, faster rinsing and diluting of the compounds concentrations of sewage origin occur. In both periods, high concentrations of trichloroethene and tetrachloroethene are identified. In the second period, a drop in identification frequency (partly intensity) has been recognized, as for agricultural indicators. Values and the dynamics of identification for these two compounds are explained by the possibility of the buried old industrial loads origin. Leaching is increased in the rainy season, resulting in a higher incidence of these pollutants in groundwater.

\section{Conclusions}

Passive sampling was applied for quality monitoring of organic contaminants in coarse gravel aquifer of Vrbanski plato. Passive samplers with granular activated carbon were installed in monitoring boreholes and in the Drava River. In two sampling series, which covered the period of one year, 161/166 organic compounds were identified. For all the compounds the frequency and intensity of the identification has been determined. In the area of the aquifer, 66 most often specified organic pollutants were separated. 40 were identified as typical indicators and were classified into groups depending on the source of pollution (agricultural, urban and industrial).

Based on the results, we found that pesticides are still one of the most problematic groups of pollutants, with organic solvents occurring in high values. Among urban pollutants, benzaldehyde, erythritol and dimethyl trisulfide have the strongest identification. The best detected pharmaceuticals are caffeine and carbamazepine, which are known as an indicator of a sewage pollution source.

With the passive sampler technique, the time dynamics of the presence of pollutants in relation to the individual periods can be observed. We found out that in the spring-summer period, the presence of organic pollutants from agricultural origin in groundwater is higher, while the pollutants of urban and industrial origin dominate in the autumn-winter period. The most frequent and more intense than any other organic pollutant are trichloroethene and tetrachloroethene, which 
behave differently than other industrial pollutants. We suspect this is due to the old burdens.

In our investigation, passive sampling was proved as a proper tool to assess aquifer contamination with organic compounds. In the future we will focus on improving the samplers and on the development of analytical methods.

\section{Acknowledgements}

The study presented in the paper was carried out within the project Urban Hydrogeology (L1-2261) and the research programme Groundwater and Geochemistry (P1-0020), financed by the Slovenian Research Agency.

\section{References}

[1] Wille, K., Claessens, M., Rappe, K., Monteyne, E., Janssen, C. R., De Brabander, H. F. \& Vanhaecke, L., Rapid quantification of pharmaceuticals and pesticides in passive samplers using ultra high performance liquid chromatography coupled to high resolution mass spectrometry. Journal of Chromatography A, 1218 (51), pp. 9162-9173, 2011.

[2] Kot, A., Zabiegala, B. \& Namiesnik, J., Passive sampling for long-term monitoring of organic pollutants in water. TrAC Trends in Analytical Chemistry, 19 (7), pp. 446-459, 2000.

[3] Nyoni, H., Chimuka, L., Vrana, B. \& Cukrowska, E., Membrane assisted passive sampler for triazine compounds in water bodies - Characterization of environmental conditions and field performance. Analytica Chimica Acta, 694 (1-2), pp. 75-82, 2011.

[4] Seethapathy, S., Gorecki, T. \& Li, X., Passive sampling in environmental analysis. Journal of Chromatography A, 1184 (1-2), pp. 234-253, 2008.

[5] Vermeirssen, E. L. M., Bramaz, N., Hollender, J., Singer, H. \& Escher, B. I., Passive sampling combined with ecotoxicological and chemical analysis of pharmaceuticals and biocides - evaluation of three Chemcatcher ${ }^{\mathrm{TM}}$ configurations. Water Research, 43 (4), pp. 903-914, 2009.

[6] Mali, N., Brenčič, M. \& Urbanc, J., Analiza vpliva črpanja na Vrbanskem platoju na gibanje podtalnice. Geološki zbornik, 10, pp. 38-41, 1996.

[7] Mali, N., Herič, J. \& Prestor, J. Izvedba dveh vodnjakov pri Mariborskem otoku - priprava in izvedba 60 dnevnega črpalnega poskusa. Geološki zavod Slovenije: Ljubljana, pp. 2-8, 2003.

[8] Auersperger, P., Lah, K., Kramarič Zidar, V. \& Mali, N. 2011. Kvalitativni monitoring organskih onesnaževal $\mathrm{v}$ podzemni vodi $\mathrm{z}$ uporabo pasivnega vzorčenja in plinske kromatografije $\mathrm{z}$ masno spektrometrijo $=$ Qualitative monitoring of organic pollutants in groundwater by passive sampling and gas chromatography mass spectrometry. Proc. Of the Slovenski kemijski dnevi 2011, eds. Z. Kravanja, D. Brodnjak-Vončina \& M. Bogataj, FKKT: Portorož, 2001.

[9] EURACHEM/CITAC Guide: The Expression of Uncertainty in Qualitative Testing, EURACHEM/CITAC: Teddington, pp. 7-17, 2003. 